\title{
A Patento-Scientometric Approach to Venture Capital Investment Prioritization
}

Article in Journal of the Association for Information Science and Technology · April 2015

DOI: $10.1002 / a s i .23205$

CITATIONS

READS

3

3 authors:

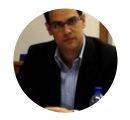

Gustavo Da Silva Motta

Universidade Federal Fluminense, Brazil, Volta..

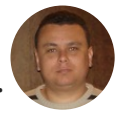

Pauli Garcia

27 PUBLICATIONS 13 CITATIONS

Universidade Federal Fluminense

SEE PROFILE

27 PUBLICATIONS 100 CITATIONS

SEE PROFILE

Rogério Hermida Quintella

Universidade Federal da Bahia

40 PUBLICATIONS 48 CITATIONS

SEE PROFILE 


\title{
A Patento-Scientometric Approach to Venture Capital Investment Prioritization
}

\author{
Gustavo da Silva Motta and Pauli Adriano de Almada Garcia \\ Universidade Federal Fluminense / Universidade Federal da Bahia, R. Des. Ellis H. Figueira, 783, Aterrado, \\ 27213-415, Volta Redonda/RJ, Brasil. E-mail: gustavosmotta@gmail.com, pauliadriano@id.uff.br \\ Rogério Hermida Quintella \\ Universidade Federal da Bahia, Av. Reitor Miguel Calmon S/N, Vale do Canela, 41110-100, Salvador, Brasil. \\ E-mail: rhquintella@gmail.com
}

This paper proposes an approach to analyzing and prioritizing venture capital investments with the use of scientometric and patentometric indicators. The article highlights the importance of such investments in the development of technology-based companies and their positive impacts on the economic development of regions and countries. It also notes that the managers of venture capital funds struggle to objectify the evaluation of investment proposals. This paper analyzes the selection process of 10 companies, five of which received investments by the largest venture capital fund in Brazil and the other five of which were rejected by this same fund. We formulated scientometric and patentometric indicators related to each company and conducted a comparative analysis of each by considering the indicators grouped by the nonfinancial criteria (technology, market, and divestiture team) from analysis of the investment proposals. The proposed approach clarifies aspects of the criteria evaluated and contributes to the construction of a method for prioritizing venture capital investments.

\section{Introduction}

In knowledge-based economies, growth is increasingly dependent on innovation (Wonglimpiyarat, 2010). In the innovation process, access to sources of financing is critical (Bygrave \& Timmons, 1992; Freeman \& Soete, 1997; Hyytinen \& Toivanen, 2005; Pissarides, 1999). However, a brief review of the literature shows that venture capital (VC) is the most common and important source of

Received March 21, 2013; revised November 12, 2013; accepted November 29, 2013

(C) 2014 ASIS\&T • Published online 21 May 2014 in Wiley Online Library (wileyonlinelibrary.com). DOI: 10.1002/asi.23205 financial support for the development of technology-based companies, when the main focus is investment in innovation (Barry, Muscarella, Peavy, \& Vetsuypens, 1990; Bygrave \& Timmons, 1992; Fredricksen, Olofsson, \& Wahlbin, 1997; Gompers \& Lerner, 2001; MacMillan, Zemann, \& SubbaNarisimha, 1989; Schefczyk \& Gerpott, 2001; Wonglimpiyarat, 2010).

There are many studies showing that VC investments in emerging technologies, both from public and private sources, provide a significant competitive advantage to the U.S. economy (e.g., Edwards 1999; European Commission 1998; Florida and Kenney 1988). VC activity in the United States accounts for annual investments on the order of billions of dollars (Denis, 2004). These investments are important because they generate continuous innovations (Gompers, Lerner, \& Sharfstein, 2005) with a strong potential for the development of firms, sectors, and segments as well as the economy as a whole (Dimov \& Murray, 2008).

Despite its importance in developed economies, such as the United States, VC investing is still in the embryonic stages in some newly industrializing economies. In Brazil, for example, these investments only began in the $1980 \mathrm{~s}$ (Santos \& Dutra, 2005) and only since the 2000s have they been increasing in value (Garcez \& Anselmo, 2005). The growth of the VC segment in Brazil is associated with improvement in the competitive landscape in the country, prompting firms to develop new technologies to better compete in the global marketplace (Cortes, 2010).

As noted by several studies (Bank of England, 1996; Dimov \& Murray, 2008; European Commission, 1998; Storey \& Tether, 1998; ), early-stage technology firms are vulnerable to the scarcity of capital even when it comes to VC. This is because such investments, known as seed investments, present the greatest risks because of the uncertainty 
regarding the technical, market, and organizational viability related to them (Day, Schoemaker, \& Gunther, 2000).

This reality is particularly important where the uncertainties are large, such as in the Brazilian case, due to (a) an unclear regulatory environment (IETS, 2002), (b) an immature national system of innovation (Albuquerque, 2003; Rapini et al., 2009), (c) a lack of a corporate culture of investment in research and development (Dagnino, 2010), and (d) its history of high interest rates (Sicsu \& Oliveira, 2003) among other factors. All of these factors make investors more risk averse.

Confirming these observations, the work of Carvalho, Ribeiro, and Furtado (2006) shows that in Brazil the approval rate of projects by VC investors is only $1 \%$. Hence, these investors naturally need to evaluate many business plans with the intention of selecting a few of the most promising ventures at the front the local class. The basis of such assessments regarding the potential of the innovative design considers multiple criteria, which in this study are classified as in Motta and Quintella (2012): exclusively financial criteria and nonfinancial criteria.

The financial criteria include instruments widely accepted for the evaluation process. Examples are analyses of risk, the breakeven point, cost structure, return on invested capital, and projected cash flow, among others. The nonfinancial criteria, in turn, bring the need to objectify a process naturally involving subjective judgments, which are as a rule at the mercy of the personal evaluation of managers (Motta \& Quintella, 2012). This is especially evident when it is necessary to evaluate projects from different areas of technology.

Considering the presented context, as well as due to the difficulty that managers of VC funds have to objectify the evaluation of investments, this article proposes an approach to analyze and prioritize them. The research that underlies the approach presented in this paper considers the scientometric and patentometric indicators of 10 companies, five of which received investments from the largest VC fund in Brazil and five did not.

This article is divided into six parts, including this Introduction. The second part presents a review of the literature used for the definition of $\mathrm{VC}$ and the criteria used by $\mathrm{VC}$ investors for investment proposal evaluation. Following this, we present a brief case description, followed by the procedures, the data collected in the survey, and finally the conclusions and limitations of this study.

\section{Venture Capital}

VC came to prominence in the United States in the 1950s and is acknowledged as having played an important role in the development of Silicon Valley and numerous technology-based firms. VC investments produce significant impacts on innovations developed within companies, job creation, and economic growth in regions and the country as a whole (Birch, 1979; Dushnitsky \& Lenox, 2005; Global Insight, 2007; Kortum \& Lerner, 2000).
Gompers and Lerner (2001) define VC investing as financial intermediation between entrepreneurs and investors for the development of technology-based companies, which are typically small, emerging, and uncertain. Investors assume high risk in acquiring a stake in the venture, but reap commensurately high profits from successful enterprises. From this definition, some characteristics involving $\mathrm{VC}$ can be emphasized: (a) the presence of two agents (investor and investee); (b) investment in enterprises perceived to have a potential for high return, due to the development of innovative technology; and (c) high risks.

In a $\mathrm{VC}$ transaction there are, on one hand, entrepreneurs looking for funds to create or expand their business, and on the other investors seeking an opportunity to make an investment in an enterprise with a high upside (Gompers \& Lerner, 2001). In this article, we chose to focus on the investor by formulating input criteria for the process of selecting investment opportunities.

Thus, considering the view of investors when analyzing the second characteristic of VC (high return), it can be stated that they will only risk their capital in projects that demonstrate potential for above-average return. Oakey (1984) justifies this potential by noting that it is technology-based companies that have the greatest likelihood of return, primarily because they operate in markets with few competitors and their products can only be copied by researchers who master that specific technological area.

On the other hand, the third component of the definition of Gompers and Lerner (2001) implies that technologybased companies, the target of VC investors, bring inherent uncertainty and risk. So by purchasing an equity stake in a new start-up, the VC investor lacks the safeguards common in other types of financial transactions, such as loans (guarantors, mortgages, liens, etc.). That is, if the target business does not perform as projected, the venture capitalist will likely suffer a loss, possibly amounting to the total invested. Therefore, before making the investment, such investors should carefully consider their options and opportunities (Battini, 1985), focusing on reducing the risks inherent in innovation, especially market risk, technology risk, and organizational risk (Day et al., 2000).

In this context, MacMillan et al. (1989) identified the main focuses of the criteria used by venture capitalists to evaluate investment proposals: (a) the entrepreneur and the project team, (b) the product (or technology), (c) the market, and (d) the projected financial results. Thus, for these authors, the analysis of entrepreneurs and their teams should consider their track record and competence to realize the potential of the technology and the business. The analysis of the product (or technology), in the view of MacMillan et al. (1989), should strongly consider the possibility of intellectual property protection, and the market analysis should find a high potential growth rate. Finally, these authors consider the fundamental aspects of financial analysis: high growth potential and high liquidity of the investment. 
Cumming (2008) adds a fifth criterion to the four criteria established by MacMillan et al. (1989): the outlook for divestment. According to Cumming and MacIntosh (2003), there are five possible ways the $\mathrm{VC}$ investor can divest an enterprise: (a) acquisition (or merger), in which the investor and the entrepreneur sell their shares to a large company that has an interest in the technology/business; (b) initial public offering (IPO); (c) sale of the shareholding to other investors; (d) sale of the shareholding back to the entrepreneur; and (e) liquidation of the investment (write-off).

Possibly due to the frequency with which they are adopted in studies and in organizations as well as the support found in the literature, the following five criteria are widely used for the evaluation of technology-based enterprises: (a) team, (b) technology, (c) market, (d) financial projection, and (e) divestment. As previously mentioned, the criteria that are not purely financial do not rely on objective evaluation tools, usually involving subjective evaluation by the investor.

\section{Case Description}

In this case study, we use the process of project selection of a VC fund whose focus is on seed investment because investing in emerging companies carries greater risks. The fund chosen (Criatec) is the largest seed capital investor in Brazil (Cortes, 2010).

Criatec was established on the initiative of the National Bank for Economic and Social Development (BNDES). It began operating in November 2007, with a net worth of $\mathrm{R} \$ 100$ million ( US\$ 500,000). Its shares were underwritten by BNDESpar (the equity investment arm of the BNDES) and Banco do Nordeste do Brasil (BNB) (CGEE, 2008).

According to Cortes (2010), Criatec considers several factors in its selection process of companies, such as the size and evaluation of the project. Regarding the size of the projects analyzed for investment, Criatec divides the projects under consideration into two types of opportunities: (a) businesses with revenue of up to $\mathrm{R} \$ 6$ million/year, with a high projected return, and (b) research entrepreneurs who have technologies with high market potential in the completed research or prototype/pilot plant phases and intend to create companies to market these technologies. Regarding the evaluation of the projects, criteria similar to those raised in the literature review (Cumming, 2008; Cumming \& MacIntosh, 2003; MacMillan et al., 1989) are considered, namely, (a) team, (b) technology, (c) market, (d) financial projection, (e) need for capital, and (f) divestment. The only criterion that differs between the literature and Criatec is that of the need for capital because to receive an investment from this fund, the company must have a need for up to $\mathrm{R} \$ 1.5$ million. As this is an exclusively financial criterion, this difference does not interfere with this study because our focus is on nonfinancial criteria.
The selection processes were analyzed with regard to 10 companies, five of which received investments and five that were rejected by Criatec. The data and companies were analyzed between 2007 and 2010. To protect their identities, the real names of the companies are not presented and they are identified throughout this article as i-1, i-2, i-3, i-4, and $\mathrm{i}-5$, for the five invested companies, and r-1, r-2, r-3, r-4, and r-5 for the five rejected by Criatec.

Company i-1 produces and applies Pochonia chlamydosporia, a fungus that grows on the surface of plant roots (mycorrhizal fungus) and colonizes accumulations of nematode eggs, destroying or controlling the multiplication of pests that affect many crops. Thus, the technology of this company is defined as being the application of the fungus $P$. chlamydosporia as a nematidcide on diverse crops.

Company i-2 manufactures printers for marking polymers and metals using lasers. Its clients are major industries from different sectors that use these machines to print anticounterfeit labels on their packaging. Thus, its technology is considered as being the process of laser marking metals and polymers.

Company i-3 operates in chemical technology and specializes in extracting antioxidants from Amazonian fruits to market them as raw material for makers of processed foods, cosmetics, and pharmaceuticals. Its technology is thus defined as production and sale of polyphenols and antioxidants extracted from plants.

Company i-4 develops veterinary drugs that have probiotics in their formulation. Thus, the technology of this company is defined as being probiotics for veterinary applications.

Finally, company i-5 specializes in the manufacture of advanced ceramic products that use silicon darbide ( $\mathrm{SiC}$ ) to be used in various industrial sectors. Thus, its technology is defined as the use of different ceramic materials developed based on silicon carbide ( $\mathrm{SiC})$.

Company $\mathrm{r}-1$ develops precision farming equipment for dose adjustment to obtain equal concentrations of the solution in the soil, regardless of spatial position. Thus, its technology is defined as precision herbicide application.

Company r-2 produces organomineral fertilizers applied to a wide range of agricultural settings. Thus, its technology is defined as organomineral fertilizer production.

Company r-3 develops data acquisition systems for monitoring electric power generators. The system transforms the signals from the generator system into management information. Thus, the technology is defined as the development of data acquisition systems.

Company r-4 supplies a system for usage-record treatment that supports performance management of telecommunications networks. Thus, its technology is treatment systems for telecom network use records.

Finally, company r-5 develops hematological diagnostic equipment for medical applications based on optical processes. Thus, its technology is defined as the use of optical processes for hematological diagnosis. 
For construction of the scientometric and patentometric indicators, we used data related to the technologies of each company found in articles published in journals, indexed in the Web of Science (WoS), as well as patents filed worldwide, available in the Derwent Innovation Index (DII). These sources were chosen because they both belong to Thomson Reuters, hence facilitating the standardization of data relating to different documents (articles and patents), and are available free of charge to researchers from Brazilian public universities.

\section{Method}

In this section, divided into three subsections, we present the method used in this study. The first section outlines the search strategies we used to find the information about the technologies of each company. Next, the procedures are presented: first, the building of the scientometric and patentometric indicators related to each company in the case study and, second, the comparative analysis of each of these companies considering the indicators grouped by nonfinancial criteria for analyzing investment proposals.

\section{Search Method}

The search terms used to extract data from the sources, relating to $\mathrm{i}-1$, were the expressions: "Pochonia Chlamydosporia"- the name of the fungus produced by company i-1, "Verticillium Chlamydosporium"—its old name, and "nematicide" - its function. For i-2 we used the terms "laser" and "mark*" (which encompasses all possible variations for the word mark "mark," "marks," "marker," "marking"), excluding medical (lasers are widely used in surgical procedures, for example), biological, chemical, and other areas that do not match the technological application of i-2. For i-3, the terms were "polyphenols" and "antioxidant," and ("plant" or "Amazonian Plant"). The search term for i-4 was basically "probiotic," restricted to the area of veterinary science. The search built for i-5 considered the expression "silicon carbide" and the term "ceramic" associated with the term "material*" through the proximity operator "NEAR." For r-1, the terms were ("precision farming" or "precision agriculture") and (herbicide or weedkillers). The search term for r-2 was "organomineral fertilizer" and for r-3 was "data acquisition systems." Relating to $r-4$, the search terms were "usage record" or "usage records." Finally, to extract data for $\mathrm{r}-5$, we used the expressions "blood diagnosis" and "optical process." The data sets extracted defined what are called, during the process of analysis in this article, Company Area, both in terms of science (articles) and in terms of technology (patents).

After data extraction from the articles and patents related to the technologies of the 10 companies evaluated in this study, we cleaned them up and standardized them, eliminating redundant or inconsistent data. The completion of this step, which was carried out using VantagePoint software v. 7, identified:
- Number of articles by year of publication;

- Number of patents by year of priority;

- Countries of the organizations/institutions to which the authors of the articles are affiliated;

- Countries where technologies are protected by patents (Designated Country);

- Organization affiliation of the authors of the articles and its type (business, academic, or government);

- Organization that holds the patent rights and its type (business, academic, or government);

- Specifics of the companies;

- Topics of interest of the articles from the Subject Category WoS;

- Topics of interest of the patents from the International Patent Classification (IPC).

To analyze the correlation between the Topics of Interest of patent documents and papers required the integration and adaptation of the classifications, which was done through the technological fields proposed by IPC-Technology Concordance Table of the WIPO (World Intellectual Property Organization). With this information identified, we constructed the scientometric and patentometric indicators that could assist the process of choosing investment proposals.

\section{Construction of the Scientometric and Patentometric Indicators}

The indicators constructed for benchmarking the companies are presented in this section and divided by the evaluation criteria they involve.

Technology criterion. The technology criterion was subdivided into dimensions (a) scientific publication and (b) utilization of opportunities. Thus, the first dimension finds the level of scientific publication related to the technologies evaluated, considering this as evidence of a scientific basis that allows for technological development (Guimarães \& Humman, 1995; Leite, Mugnaini \& Leta, 2011). The second dimension searches for evidence of the use of the knowledge produced by looking for its transformation into technology, more specifically, through the process of patenting (Albuquerque, 1997, 1998; Albuquerque \& Sicsú, 2000; Leydesdorff, 2008).

So, as shown in Figure 1, the scientific publication dimensions have indicators defined as:

- Number of papers, which measures the total number of papers in a given area (Guimarães \& Humman, 1995; Leite, Mugnaini, \& Leta, 2011; Macias-Chapula, 1998; Okubo, 1997);

- Scientific growth, which helps identify whether the area is in a phase of scientific growth, maturity, or decline (Guimarães \& Humman, 1995; Leite, Mugnaini, \& Leta, 2011; Macias-Chapula, 1998; Okubo, 1997);

- Topics of interest correlation, which shows the degree of interaction between science and technology (Bassecoulard \& Zitt, 2004; Bhattacharya, Kretschmer, \& Meyer, 2003; Maricato, 2010); and 


\begin{tabular}{|l|l|l|}
\hline Criterion & Dimension & \\
\hline \multirow{4}{*}{ Technology } & \multirow{4}{*}{$\begin{array}{c}\text { Scientific } \\
\text { Publication }\end{array}$} & Indicator \\
\cline { 3 - 3 } & & Scientific growth \\
\cline { 3 - 3 } & & Topics of interest correlation \\
\cline { 3 - 3 } & \multirow{2}{*}{$\begin{array}{l}\text { Utilization of } \\
\text { Opportunities }\end{array}$} & Number of patents \\
\cline { 3 - 3 } & & Utilization of Opportunities Indicator (UOI) \\
\cline { 3 - 3 } & & \\
\hline
\end{tabular}

FIG. 1. Indicators and dimensions of the technology criterion.

- International scientific collaboration, whose existence is seen by many researchers (Adams, King, \& Singh, 2009; Maricato, 2010; National Science Foundation, 2010) as a sign of maturity, because the trend is for newer areas to be initially studied by researchers in the same country (it takes a certain amount of maturity before degrees of collaboration with other countries are seen).

As for the utilization of opportunities dimension, which measures the level of transformation of the production of knowledge into technology, the indicators were defined as:

- Number of patents, which measures the total number of patents in a given area (Guzmán Sánchez, 1999; Macias-Chapula, 1998);

- Utilization of Opportunities Indicator (UOI), which gives indications about the quality of the interactions between science and technology through the ratio of the number of patents to the number of articles in a given area (Albuquerque, 1997, 1998; Albuquerque \& Sicsú, 2000); and

- Technological growth, which helps identify whether the area is in a phase of technological growth, maturity, or decline (Guzmán Sánchez, 1999; Leydesdorff, 2008; Macias-Chapula, 1998).

Market criterion. The second criterion includes the commercial potential of the technology in the analysis (MacMillan et al., 1989). Here we use the number of originating countries of scientific papers as an indicator of pool of knowledge, and we consider the number of countries covered by the patents as an indicator of demand. Thus, the market criterion's dimensions are (a) pool of knowledge and (b) demand.

Figure 2 presents selected indicators for these two dimensions. In the pool of knowledge dimension, which assesses the ability to supply knowledge to the production of technology, we used the following indicators:

- Number of countries in scientific production, which measures the inclusion of certain thematic research agendas of different countries, demonstrating the supply of knowledge in them (Guimarães \& Humman, 1995; Leite, Mugnaini, \& Leta, 2011; Macias-Chapula, 1998; Okubo, 1997);

\begin{tabular}{|l|l|l|}
\hline Criterion & Dimension & \multicolumn{1}{|c|}{ Indicator } \\
\hline \multirow{4}{*}{ Market } & \multirow{2}{*}{$\begin{array}{c}\text { Pool of } \\
\text { Knowledge }\end{array}$} & Number of countries in scientific production \\
\cline { 3 - 3 } & & Growth of international scientific interest \\
\cline { 3 - 3 } & \multirow{4}{*}{ Demand } & Brazilian participation in scientific production \\
\cline { 3 - 3 } & & Sumber of designated countries \\
\cline { 3 - 3 } & & Scope of patents in designated countries \\
& & Brazilian participation in world trade interest \\
\hline
\end{tabular}

FIG. 2. Indicators and dimensions of the market criterion.

- Growth of international scientific interest, which measures the rate of growth of international scientific interest (Guimarães \& Humman, 1995; Leite, Mugnaini, \& Leta, 2011; Macias-Chapula, 1998; Okubo, 1997); and

- Brazilian participation in scientific production, which indicates the importance given to the subject at the national level, allowing for international comparisons (Albuquerque, 2003; Maricato, 2010).

For the demand dimension, the indicators were defined as:

- Number of designated countries, which represents the countries where the owner of the patent demonstrates commercial interest (Alcacer \& Gittelman, 2004; Griliches, 1990; Maricato, 2010);

- Growth of international trade interest, which measures the rate of growth of international technological interest (Griliches, 1990; Maricato, 2010);

- Scope of patents in designated countries, indicating the extent of the patents in the designated countries (Alcacer \& Gittelman, 2004; Griliches, 1990); and

- Brazilian participation in world trade interest, which indicates the level of national patenting, allowing for international comparisons (Albuquerque, 2003; Maricato, 2010).

Divestment criterion. The main focus of the evaluation of the divestment criterion is the withdrawal from the seed capital fund of the stakes held in the companies by the investors. This research identifies potential organizations that have an interest in the technologies of the companies evaluated, which makes it possible to identify, in light of the proxy assumed here, likely buyers of technology. As academic and government organizations do not acquire stakes in private companies except in cases involving their constitution (which is not the case for disinvestment), to evaluate this criterion we considered business organizations with published articles or patents related to the areas/companies evaluated, divided into the following two dimensions: (a) scientific production, (b) technological production.

Figure 3 presents indicators for the two dimensions of the divestment criterion. For the scientific production dimension, the following indicators were used: 


\begin{tabular}{|l|l|l|}
\hline Criterion & Dimension & \multicolumn{1}{|c|}{ Indicator } \\
\hline \multirow{4}{*}{ Divestment } & \multirow{2}{*}{$\begin{array}{c}\text { Scientific } \\
\text { Production }\end{array}$} & Number of firms in scientific production \\
\cline { 3 - 3 } & & Growth of scientific interest from firms \\
\cline { 3 - 3 } & \multirow{2}{*}{$\begin{array}{c}\text { Technological } \\
\text { Production }\end{array}$} & Mean of papers from firms \\
\cline { 3 - 3 } & & Growth of technological interest from firms \\
\cline { 3 - 3 } & & Mean of patents from firms \\
\hline
\end{tabular}

FIG. 3. Indicators and dimensions of the divestment criterion.

- Number of firms in scientific production, which indicates the business interest in scientific development in the area (Guimarães \& Humman, 1995; Leite, Mugnaini, \& Leta, 2011; Macias-Chapula, 1998; Okubo, 1997);

- Growth of scientific interest from firms, which measures the growth rate of scientific interest in the business (Guimarães \& Humman, 1995; Leite, Mugnaini, \& Leta, 2011; Macias-Chapula, 1998; Okubo, 1997); and

- Average number of papers from firms, which demonstrates the volume of scientific production of companies (Guimarães \& Humman, 1995; Leite, Mugnaini, \& Leta, 2011; Macias-Chapula, 1998; Okubo, 1997).

As for the size of technological production, we considered the following indicators:

- Number of firms in technological production, which measures the business interest in technological development in the area (Alcacer \& Gittelman, 2004; Griliches, 1990; Guzmán Sánchez, 1999; Macias-Chapula, 1998);

- Growth of technological interest from firms, which measures the growth rate of technological interest in the business (Alcacer \& Gittelman, 2004; Griliches, 1990; Guzmán Sánchez, 1999; Macias-Chapula, 1998); and

- Average number of patents from firms, which demonstrates the volume of technological production of companies (Alcacer \& Gittelman, 2004; Griliches, 1990; Guzmán Sánchez, 1999; Macias-Chapula, 1998).

Each of the first three criteria (technology, market, and divestment) used indicators for areas of enterprise, with the goal of gaining a broader understanding of the potential of each company being considered for investment by the fund under these aspects. One must also consider data related specifically to the company being evaluated by comparing them to those being evaluated more broadly.

Team criterion. The team criterion was subdivided into two dimensions: (a) scientific basis and (b) technological protection. The analysis of the scientific basis allows consideration of indicators of the competence of teams in the development of each technology/product under consideration and also the ability to use that basis to develop new products. This way it is possible to build a portfolio with the intention of reducing the risks of such investments (Day et al., 2000; MacMillan et al., 1989).

\begin{tabular}{|c|c|c|}
\hline Criterion & Dimension & Indicator \\
\hline \multirow{8}{*}{ Team } & \multirow{4}{*}{ Scientific Basis } & Number of papers from team \\
\hline & & Team international scientific collaboration \\
\hline & & Team scientific collaboration with other organizations \\
\hline & & Team participation in global scientific production \\
\hline & \multirow{4}{*}{$\begin{array}{l}\text { Technological } \\
\text { Protection }\end{array}$} & Number of patents from team \\
\hline & & Team international technological collaboration \\
\hline & & $\begin{array}{l}\text { Team technological collaboration with other } \\
\text { organizations }\end{array}$ \\
\hline & & Team participation in global technological production \\
\hline
\end{tabular}

FIG. 4. Indicators and dimensions of the team criterion.

The technological protection indicator can also be used to reduce the risk of investment by seed capital funds. It indicates that the technology would not be easily copied and that its exploitation could only be performed by other companies with the consent of the patent holder (Guzmán Sánchez, 1999).

As shown in Figure 4, the indicators defined for the scientific basis dimension are:

- Number of papers from the team, which measures the total number of articles authored by members of the staff in that area (Guimarães \& Humman, 1995; Leite, Mugnaini, \& Leta, 2011; Macias-Chapula, 1998; Okubo, 1997);

- Team's international scientific collaboration, which demonstrates the integration and maturity of the team in international scientific production (Adams et al., 2009; Maricato, 2010; National Science Foundation, 2010);

- Team's scientific collaboration with other organizations, which identifies the relationship of team members with researchers from other organizations in scientific production (Maricato, 2010); and

- Team's participation in global scientific production, which indicates the level of scientific production by the team, allowing for international comparisons (Albuquerque, 2003; Maricato, 2010).

In terms of technological protection, we considered:

- Number of patents from the team, which measures the total number of patents owned or co-owned by the team members/company in the area (Guzmán Sánchez, 1999; Macias-Chapula, 1998);

- Team's international technological collaboration, which measures the cooperation of the team in technological production with organizations in other countries (Guzmán Sánchez, 1999; Macias-Chapula, 1998; Maricato, 2010);

- Team's technological collaboration with other organizations, which demonstrates that the cooperation of the team members with other organizations in technological production (Maricato, 2010); and

- Team's participation in global technological production, which indicates the level of technological production of 
the team, allowing for international comparisons (Guzmán Sánchez, 1999; Macias-Chapula, 1998; Maricato, 2010).

\section{Comparative Analysis}

In considering multiple criteria, which is one of the purposes of this paper, there are several different approaches available for prioritizing options. In this study we use an approach based on data envelopment analysis (DEA) because it is a globally widespread and consolidated method. Therefore, the next subsection provides a discussion of DEA and its main models to address the problem at hand.

Data envelopment analysis. DEA is a method of analysis based on linear programming, where different decisionmaking units (DMUs) are compared. Therefore, it is important that the same criteria, both input and output, be considered, varying only in their respective levels (Charnes, Cooper, Lewin, \& Seiford, 1994; Cooper, Seiford, \& Tone, 2007; Zhu, 2009).

The most popular DEA models are the CCR (Charnes, Cooper, \& Rhodes, 1978) and the BCC (Banker, Charnes, \& Cooper, 1984). The CCR model assumes the premise of constant return to scale (CRS), whereas BCC involves variable return to scale (VRS). This means that in the first case, increases in input factors cause proportional increases in output factors. In the second case, the increments in output are not necessarily proportional to increases in input factors. For the present work, we considered only the DEA CCR model, according to Charnes et al. (1978), because it can be used for a multifaceted analysis. Nevertheless, due to the well-known problems of discrimination associated with traditional DEA models, in this paper we consider the crossevaluation approach.

Because the goal of this study was to develop an approach to the selection of projects starting by establishing an order of priority between possible investments for the VC investor, it is important to note that the best values are considered to be the highest in each criterion discussed. Thus, all of these criteria are considered as outputs in the analysis. The input is considered to be a unit value. The next section discusses this approach.

DEA model with unit input. In this paper, the variables are considered secondary, that is, either rates or combinations of primary variables. In this type of case, a classic relationship involving inputs and outputs cannot be considered. In situations such as these, DEA models should be used only considering outputs, which causes certain mathematical problems, as discussed by Lovell and Pastor (1999). To overcome these difficulties, the consideration of an input unit is critical. According to Caporaletti, Dulá, and Womer (1999) the resulting model emulates a multifaceted approach.
For Soares de Mello, Meza, and da Silva (2008), the formulation presented by Caporaletti et al. (1999) is similar to the CCR model with guidance for the inputs, with the advantage of not producing a reduction in them. Furthermore, Soares de Mello et al. (2008) also show that the BCC approach for unit inputs would be meaningless in these conditions. For this reason, we chose to use only the CCR model.

Even considering the approach with unit inputs, the traditional problems related to the discriminatory ability of DEA remain. To minimize this deficiency, we use the cross-evaluation model (Lins \& Meza, 2000; Sexton, Silkman, \& Logan, 1986). In this approach, the model evaluates each DMU under the scheme of optimal weights of other DMUs, which were obtained by the conventional DEA model.

\section{Analysis of the Data}

Table 1 shows the scientometric and patentometric indicators for each company, separated by dimension and nonfinancial evaluation criteria, as well as the results of the DEA and the value of the difference in the results from the average of all companies evaluated. This difference was used to plot graphs of criteria that are analyzed in this section.

To define the time frame of this study, we relied on UNESCO (2010), which conducted a survey and found global growth of scientific publications in general of $34.5 \%$ between 2002 and 2008. Thus, this period was considered for the construction of scientometric indicators as well as the patentometric indicators.

The scientific growth registered in the technologies of all firms surveyed is higher than the global average, as can be seen in Table 1, even for those that were rejected in the selection process.

As shown in Table 1, in the global comparison, which considered all partial results, the order of preference of the analyzed companies is (in \% unit): i-3 (98.49); i-1 (98.07); i-5 (88.35); i-2 (83.32); i-4 (82.14); r-5 (73.58); r-4 (67.53); r-3 (63.09); and r-1 (60.46) r-2 (60.40). This prioritization considered the criteria evaluated (technology, market, divestment, and team) as equally important. In this prioritization, as the five invested companies occupy the top five positions, we believe that the proposed approach, which considers the four criteria equally important, describes the selection process of the fund analyzed in this study. Therefore, we now consider the criteria separately.

In evaluating the technological criterion, illustrated in Figure 5, we observed that the scientific publication dimension responds better regarding the selection process analyzed than the utilization of opportunities dimension. All the invested companies are above the mean performance value for scientific publication and only one rejected company $(\mathrm{r}-5)$ is not below this value. Looking only at those companies in which the fund invested, we note that the ones with 


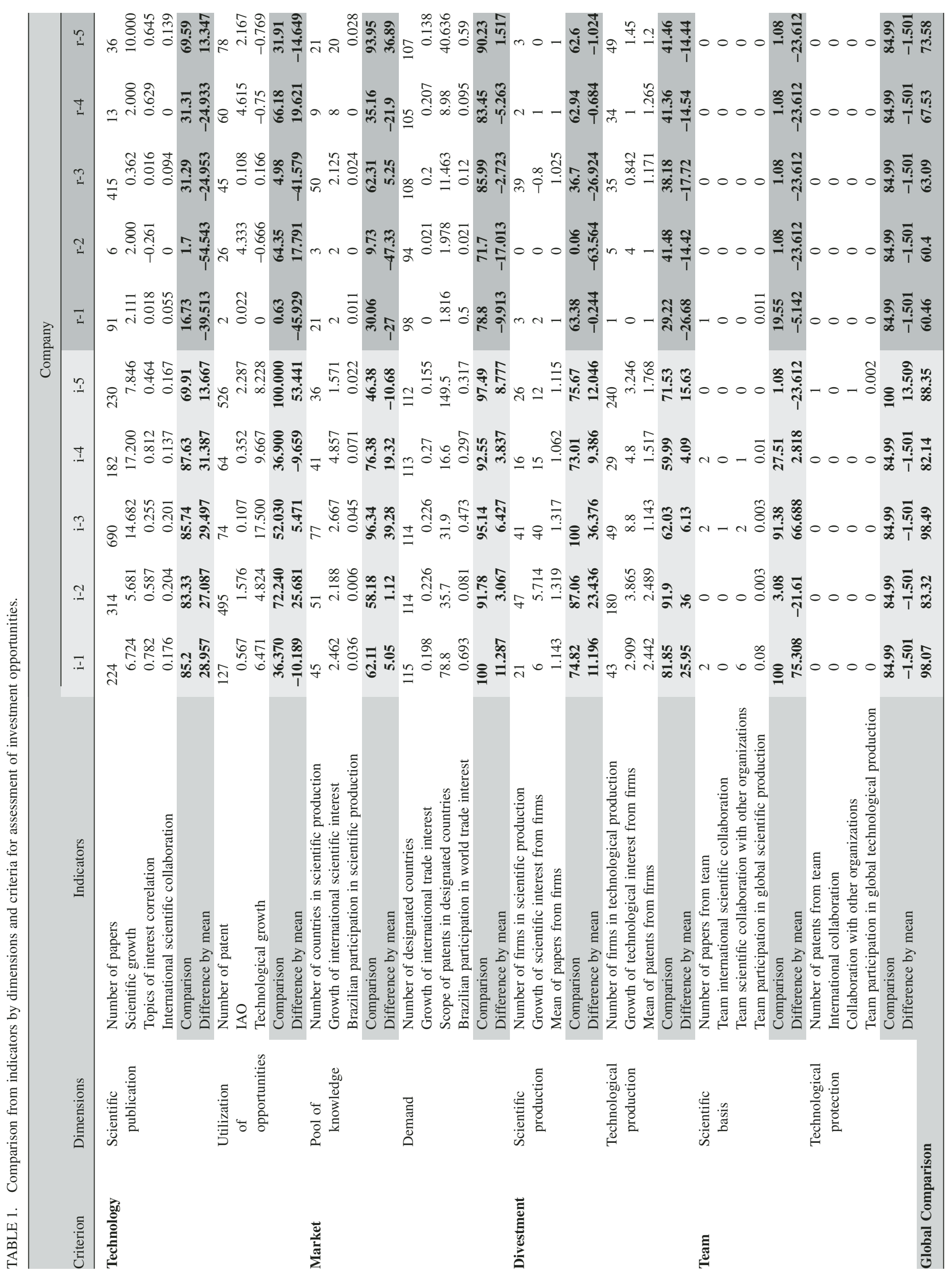




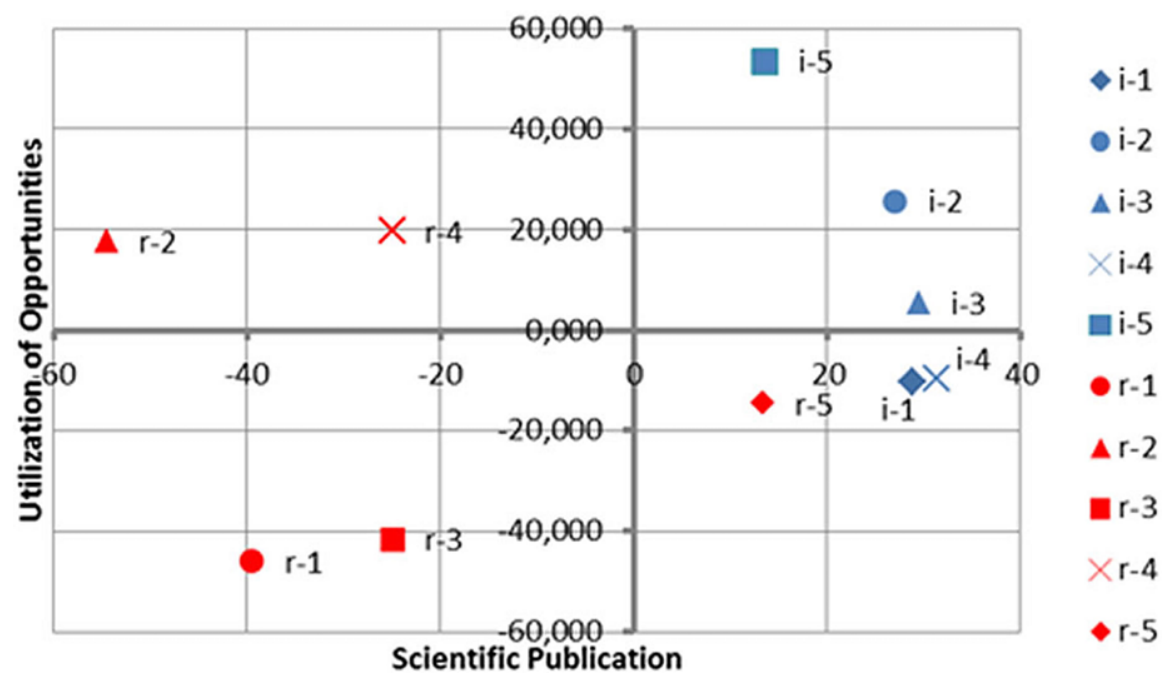

FIG. 5. Comparative position of the 10 firms in the technology criterion. [Color figure can be viewed in the online issue, which is available at wileyonlinelibrary.com.]

the highest rates of scientific publication have the lowest rates of utilization of opportunities and vice versa.

This finding highlights the fact that the dimensions assessed, at least for the invested companies, are inversely proportional. That is, among the invested companies evaluated, the larger the index of scientific publication, the smaller the index of utilization of opportunities. Thus, we can conclude that in the areas where there is greater interest in the utilization of opportunities, there is also low interest in scientific publication. This fact most likely occurs because when there is great technological potential in a given area, researchers/organizations focus more on the protection of the technology through patents and not on scientific publication, as shown in the results presented in Shelton and Leydesdorff (2012). However, the case of scientific and technological institutions (STIs) is an exception, because by virtue of their goals they strive to stimulate scientific publication. Another explanation may be because the technologies in question are emerging and therefore recent. There must be scientific maturity to eventually have a more effective technological development.

Thus, companies that have high rates of scientific publication and low rates of utilization of opportunities can operate in newer technological fields than low technological development. In terms of the implications for opportunity evaluation, it can be inferred from this analysis that companies that have high rates of scientific publication tend to have low rates of utilization of opportunities and pose higher investment risks, whereas companies with high rates of utilization of opportunities carry more moderate risks. The decision of VC investors is thus linked to their degree of risk acceptance.

The evaluation of the Market Criterion under the dimensions of pool of knowledge and demand, seen in Figure 6, indicates that all invested companies are above the mean performance value in demand, and only one rejected company ( $\mathrm{r}-5)$ is not below the average in this dimension. Thus, we observe that the demand dimension is most related to the invested companies.

Among almost all companies, there is some correlation that would indicate a direct relationship between pool of knowledge and demand. This means that the larger one is, the larger the other will be. Thus, one can expect that in countries where demand is high, there is a commitment to supply of knowledge, in order to meet the demand. Although this is intuitive when dealing with goods, for example, this is not necessarily the case when considering science and technology.

In terms of implications for the opportunity evaluation process by VC investors, when assessing the market criterion, the larger the indicators of both pool of knowledge and demand are, the better the investment should be.

Figure 7 illustrates the evaluation of the divestment criterion, under the dimensions of scientific production and technological production. It can be noted that the areas/ companies evaluated are distributed into two groups: The invested companies have high rates of technological production and scientific production, whereas the rejected companies have lower rates in both dimensions.

An association can be inferred that establishes a directly proportional relationship between the dimensions used to evaluate the divestment criterion (scientific production and technological production). Thus, the higher the focus of business organizations in terms of scientific production, the greater their technological production should be.

In this way, when considering the divestment criterion from the opportunity evaluation process, VC investors should prioritize firms that obtain the highest rates in the two dimensions. 


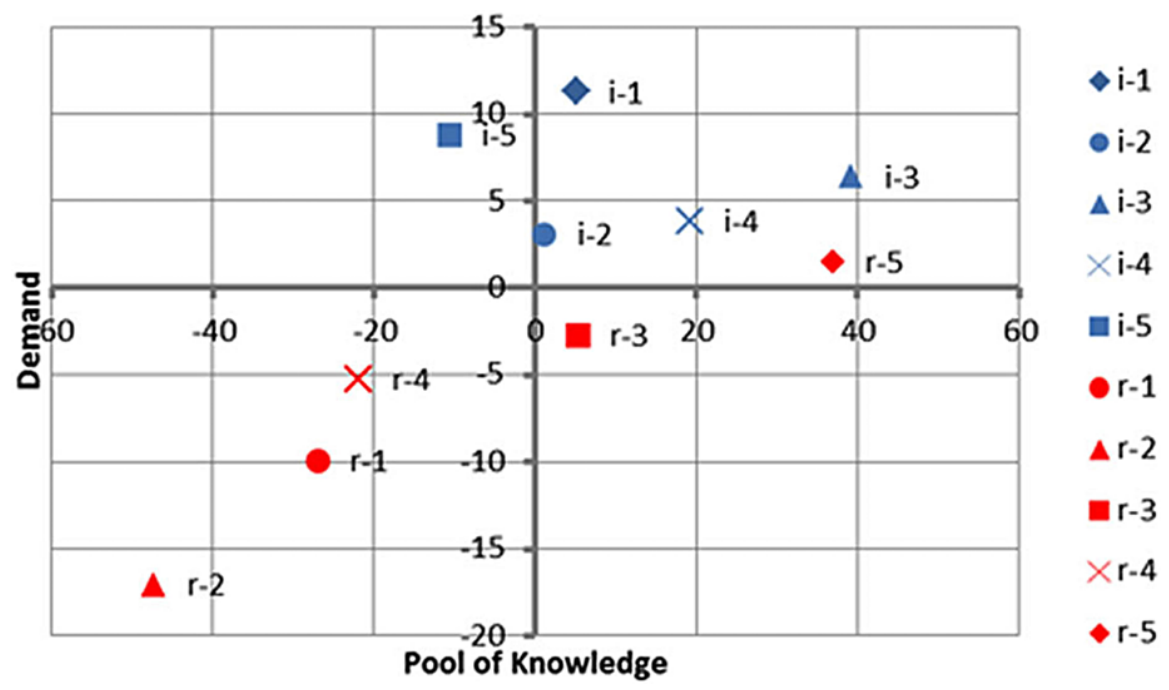

FIG. 6. Comparative position of the 10 firms in the market criterion. [Color figure can be viewed in the online issue, which is available at wileyonlinelibrary.com.]

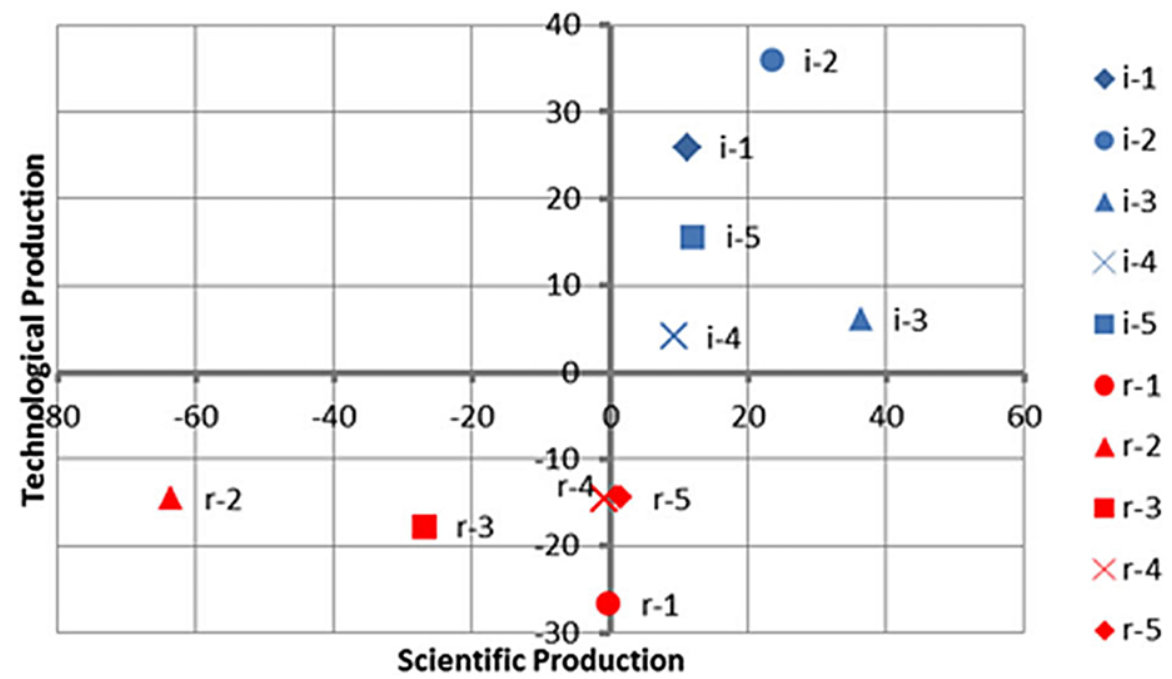

FIG. 7. Comparative position of the 10 firms in the divestment criterion. [Color figure can be viewed in the online issue, which is available at wileyonlinelibrary.com.]

Finally, Figure 8 shows the distribution of the 10 companies on the dimensions of scientific basis and technological protection, which comprise the team criterion evaluation. In this analysis, there is a clear distinction that separates i-5, with high technological protection, from the others, with low rates in this dimension. In the scientific basis dimension, i-1 and i-3 have high rates. It should be noted that the indicators that comprise the evaluation of this criterion have low values.

Most of the companies evaluated in this study do not focus on technological protection by patents, which is a characteristic of Brazilian companies (Dagnino, 2010), and only the teams of i-1 and i-3 have high rates of participation in worldwide scientific production. In terms of implications for the team criterion evaluation, $\mathrm{VC}$ investors more accustomed to risk should select companies with higher scientific capacity. The more conservative VC investor should opt for companies that have already patented their technology.

\section{Conclusions}

Based on these analyses, we conclude that scientometric and patentometric indicators not only help in understanding the issues addressed in this study related to nonfinancial criteria (technology, market, divestment, and team) but also contribute to the construction of a method for prioritizing $\mathrm{VC}$ investments. 


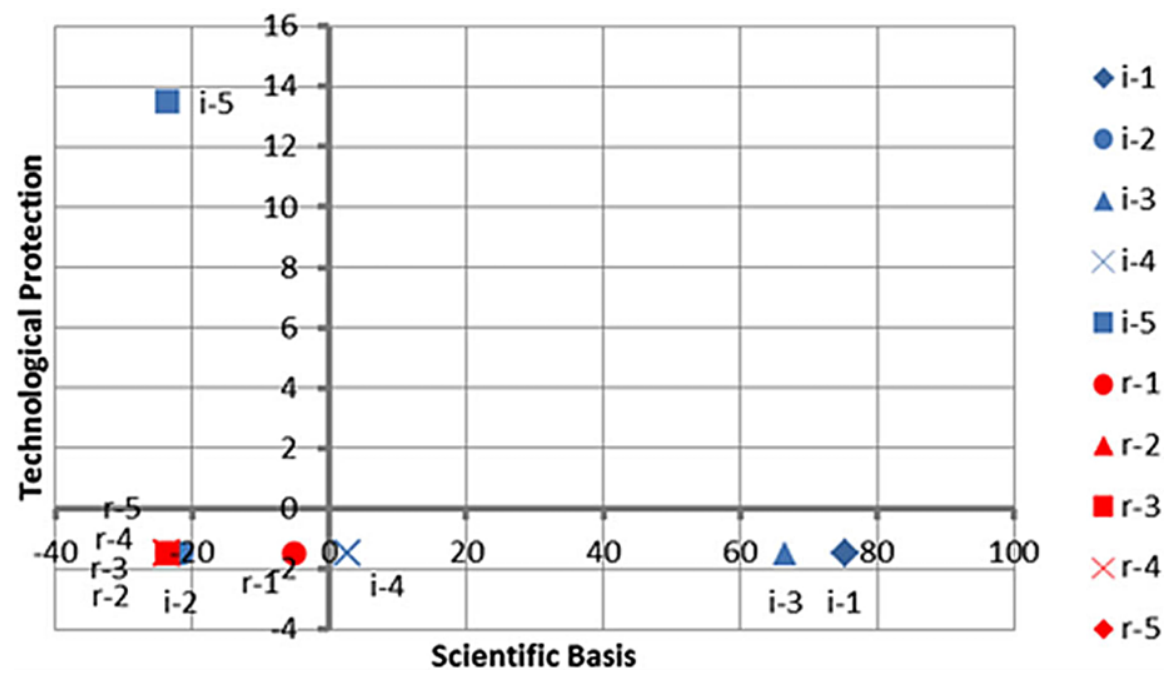

FIG. 8. Comparative position of the 10 firms in the team criterion. [Color figure can be viewed in the online issue, which is available at wileyonlinelibrary.com.]

The statistical analysis for prioritization of $\mathrm{VC}$ investment proposals, although not considering different weights for the different evaluation criteria but considering all the partial results, produces the following order of priority of the companies evaluated: i-3, i-1, i-5, i-2, i- $4, \mathrm{r}-5, \mathrm{r}-4, \mathrm{r}-3, \mathrm{r}-1$, and $\mathrm{r}-2$. As can be seen from this order, the five invested companies occupy the top five positions, so we can conclude that this approach describes, for this case, the selection process of the fund analyzed.

By analyzing the evaluation criteria separately, firms i-2 and i-3 have strengths in the technology, market, and divestment criteria; companies i- 1 and i-4 have strengths in the market and divestment criteria; company i-5 has strengths in the technology and divestment criteria; and firm r-5 is the only one among the rejected that has strengths in one criterion, in this case the market criterion. These results corroborate the combined analysis, which also prioritizes them.

Thus, the method employed here can be a useful tool for the project selection process by $\mathrm{VC}$ investors, providing greater insight into the production dynamics of science and technology as related to the products of the companies under analysis. Similarly, in a comparative analysis, it can facilitate the process of choosing between several projects, through statistical evaluations such as the data envelopment analysis used in this study.

The main limitation of this study is related to the data extraction from the WoS and IBD data bases. There is a myriad of search strategies that result in different sets of data. Still, using the same search strategy is not necessarily better for the different data bases because the logic of publishing articles differs from the logic of filing patent applications.

Also, the list of indicators constructed and the instruments used for the analysis can generate differences in the interpretation of the data. The method proposed here is therefore not intended as a definitive way to evaluate innovative emerging projects, but as an alternative to subjective evaluation criteria, through its objectification via the extraction of data from articles and patents.

As a contribution to future studies, we suggest the identification of other indicators for the same analytic criteria (technology, market, divestment, and team) as well as the definition of different weights for different nonfinancial evaluation criteria. This can be done through analysis of individual contributions to company performance. Also, by increasing the base of companies analyzed, one can reach more general conclusions.

\section{References}

Adams, J., King, C., \& Singh, V (2009). Global research report: India: research and collaboration in the new geography of science. Leeds, UK: Thomson Reuters.

Albuquerque, E.M. (1997). Notas sobre os determinantes tecnológicos do catching up: uma introdução à discussão sobre o papel dos sistemas nacionais de inovação na periferia. Estudos Econômicos, 27(2).

Albuquerque, E.M. (1998). Produção científica e sistema nacional de inovação. Ensaios FEE, Porto Alegre, 19(1), 156-180.

Albuquerque, E.M. (2003). Immature systems of innovation: Introductory notes about a comparison between South Africa, India, Mexico and Brazil based on science and technology statistics. Globelics Conference. Rio de Janeiro: Globelics.

Albuquerque, E., \& Sicsú, J. (2000). Inovação institucional e estímulo ao investimento privado. São Paulo em Perspectiva, 14(3), 108-114.

Alcacer, J., \& Gittelman, M. (2004). How do I know what you know? Patent examiners and the generation of patent citations. SSRN.

Bank of England. (1996). The financing of technology-based small firms. London: Bank of England.

Banker, R.D., Charnes, A., \& Cooper, W.W. (1984). Some models for estimating technical scale inefficiencies in data envelopment analysis. Management Science, 30(9), 1078-1092.

Barry, C.B., Muscarella, C.J., Peavy, J.W. III, \& Vetsuypens, M.R. (1990). The role of venture capital in the creation of public firms. Journal of Financial Economics, 27, 447-471. 
Bassecoulard, E., \& Zitt, M. (2004). Patents and publications: The lexical connection. In H.F. Moed, W. Glänzel, U. Schmoch (Eds.), Handbook of quantitative science and technology research. Netherlands: Kluwer Academic Press. pp. 665-714.

Battini, P. (1985). Capital et risque. Paris: Editions des Organizations.

Bhattacharya, S., Kretschmer, H., \& Meyer, M. (2003). Characterizing intellectual spaces between science and technology. Scientometrics, 58(2), 369-390.

Birch, D. (1979). The job creation process. In MIT program on neighbourhood and regional change. Cambridge, MA: MIT Press.

Bygrave, W.D., \& Timmons, J.A. (1992). Venture capital at the crossroads. Boston: Harvard Business School Press.

Caporaletti, L.E., Dulá, J.H., \& Womer, N.K. (1999). Performance evaluation based on multiple attributes with nonparametric frontiers. Omega, 27(6), 637-645.

Carvalho, A.G., Ribeiro, L.L., \& Furtado, C.V. (2006). A indústria de Private Equity e venture capital: primeiro censo brasileiro. São Paulo: Saraiva.

CGEE. (2008). Centro de Gestão e Estudos Estratégicos. Os novos instrumentos de apoio à inovação: uma avaliação inicial. Brasília: ANPEI (Associação Nacional de Pesquisa e Desenvolvimento).

Charnes, A., Cooper, W.W., \& Rhodes, E. (1978). Measuring the efficiency of decision making units. European Journal of Operational Research, 2, 429-444.

Charnes, A., Cooper, W.W., Lewin, A.Y., \& Seiford, L.M. (1994). Data envelopment analysis: Theory, methodology and applications. Boston: KAP.

Cooper, W.W., Seiford, L.M., \& Tone, K. (2007). Data envelopment analysis: A comprehensive text with models, applications, references and DEA-solver software. New York: Springer.

Cortes, H. (2010). Análise da demanda por venture capital no âmbito do FMIEE Criatec. Dissertação (mestrado em Administração). Faculdade Boa Viagem, Recife.

Cumming, D.J. (2008). Contracts and exits in venture capital finance. Review of Financial Studies, 21(5), 1947-1982.

Cumming, D.J., \& MacIntosh, J.G. (2003). A cross-country comparison of full and partial venture capital exits. Journal of Banking \& Finance, 27(3), 511-548.

Dagnino, R. (2010). Por que os "nossos" empresários não inovam? In: R. Dagnino (Ed.), Estudos sociais da ciência e tecnologia \& política de ciência e tecnologia: alternativas para uma nova América Latina. Campina Grande, Brazil: EDUEPB. pp. 47-68.

Day, G.S., Schoemaker, P.J.H., \& Gunther, R.E. (2000). Wharton on managing emerging technology. Hoboken, NJ: John Wiley \& Sons.

Denis, D.J. (2004). Entrepreneurial finance: An overview of the issues and evidence. Journal of Corporate Finance, 10(2), 301-326.

Dimov, D., \& Murray, G. (2008). Determinants of the incidence and scale of seed capital investments. Small Business Economics, 30, 127-152.

Dushnitsky, G., \& Lenox, M.J. (2005). When do incumbents learn from entrepreneurial ventures? Corporate venture capital and investing firm innovation rates. Research Policy, 34(5), 615-639. doi:10.1016/ j.respol.2005.01.017

Edwards, C. (1999). Entrepreneurial dynamism and the success of US high tech. Joint Economic Committee Staff Report, Office of the Chairman, U.S. Senator Connie Mack, Washington, DC: US Senate.

European Commission. (1998). Risk capital: A key to job creation in the European Union. Luxembourg, Belgium: Commission of the European Communities.

Florida, R., \& Kenney, M. (1988). Venture capital financed innovation and technological change in the U.S.A. Research Policy, 119-137.

Fredricksen, O., Olofsson, C., \& Wahlbin, C. (1997). Are venture capitalists firefighters? A study of the influence and impact of venture capital firms. Technovation, 17(9), 503-511.

Freeman, C., \& Soete, L. (1997). The economics of industrial innovation. London: Pinter Publishers.

Garcez, M.P., \& Anselmo, J.L. (2005). O panorama brasileiro do capital de risco: características, evolução e perspectiva. In: 11 ALTEC. Salvador: ALTEC.
Global Insight. (2007). Venture impact: The economic importance of venture capital backed companies to the U.S. economy (3rd ed.). Washington, DC: National Venture Capital Association and Content First, LLC.

Gompers, P.A., \& Lerner, J. (2001). The venture capital revolution. Journal of Economic Perspectives, 15(2), 145-168.

Gompers, P.A., Lerner, J., \& Sharfstein, D. (2005). Entrepreneurial spawning: Public corporations and the genesis of new ventures 1986 to 1999. Journal of Finance, 60(2), 577-614.

Griliches, Z. (1990). Patent statistics as economic indicators: A survey. Journal of Economic Literature, 28(4), 1661-1707.

Guimarães, J.A., \& Humman, M.C. (1995). Training of human resources in science and technology in Brazil: The importance of vigorous postgraduate program and its impact on the development of the country. Scientometrics., 34(1), 101-119.

Guzmán Sánchez, M.V. (1999). Patentometría: herramienta para el analisis de oportunidades tecnológicas. La Habana, Tesis (Gerencia de información tecnológica), Facultad de Economia. La Habana, Cuba: Universidad de La Habana.

Hyytinen, A., \& Toivanen, O. (2005). Do financial constraints hold back innovation and growth? Evidence on the role of public policy. Research Policy, 34, 1385-1403.

IETS. (2002). Criação de um ambiente favorável aos micro e pequenos negócios e desenvolvimento. Rio de Janeiro, Brazil.

Kortum, S., \& Lerner, J. (2000). Assessing the contribution of venture capital to innovation. The Rand Journal of Economics, 31(4), 674-692. doi:10.2307/2696354

Leite, P., Mugnaini, R., \& Leta, J. (2011). A new indicator for international visibility: Exploring Brazilian scientific community. Scientometrics, 88 , 311-319.

Leydesdorff, L. (2008). Patent classifications as indicators of intellectual organization. Journal of the American Society for Information Science \& Technology, 59(10), 1582-1597.

Lins, M.P.E., \& Meza, L.A. (2000). Análise Envoltória de Dados e Perspectivas de Integração no Ambiente de Apoio à Decisão. COPPE/UFRJ, Rio de Janeiro, Brazil. 2000.

Lovell, C., \& Pastor, J.T. (1999). Radial DEA models without inputs or without outputs. European Journal of Operational Research, 118(1), 46-51.

Macias-Chapula, C.A. (1998). O papel da informetria e da cienciometria e sua perspectiva nacional e internacional. Ciência da Informação, 27(2), 134-140.

MacMillan, I.C., Zemann, L., \& SubbaNarisimha, P.N. (1989). Criteria used by venture capitalists to evaluate new venture proposals. Journal of Business Venturing, 1, 119-128.

Maricato, J.M. (2010). Dinâmica das relações entre Ciência e Tecnologia: estudo Bibliométrico e Cientométrico de múltiplos indicadores de artigos e patentes em biodiesel. Tese (Doutorado)—Universidade de São Paulo, Escola de Comunicação e Artes, Programa de Pós-Graduação em Ciência da Informação, São Paulo, Brazil.

Motta, G.S., \& Quintella, R.H. (2012). Assessment of non-financial criteria in the selection of investment projects for seed capital funding: The contribution of scientometrics and patentometrics. Journal of Technology Management \& Innovation, 7(3), 172-193.

National Science Foundation. (2010). Division of Science Resources Statistics. Science and engineering indicators 2010. Arlington, VA.

Oakey, R. (1984). High technology small firms: Innovation and regional development in Britain and the United States. London: Frances Prints Publishers.

Okubo, Y. (1997). Bibliometric indicators and analysis of research systems: Methods and examples, OCDE Science, Technology and Industry Working Papers. OCDE Publishing.

Pissarides, F. (1999). Is lack of funds the main obstacle to growth? EBRD's experience with small- and medium-sized businesses in central and eastern Europe. Journal of Business Venturing, 14(5-6), 519-539.

Rapini, M., Albuquerque, E., Chaves, C., Silva, L., Souza, S., Righi, H., \& Silva da Cruz, W.M. (2009). University-industry interactions in an immature system of innovation: Evidence from Minas Gerais, Brazil. Science and Public Policy, 36(5), 373-386. 
Santos, S.A., \& Dutra, I. (2005). Capital de risco e as empresas de alta tecnologia. In S.A. Santos (Ed.), Empreendedorismo de base tecnológica: evolução e trajetória. Maringá/PR: Unicorpore.

Schefczyk, M., \& Gerpott, T.J. (2001). Management support for portfolio companies of venture capital firms: An empirical study of German venture capital investments. British Journal of Management, 12, 201-216.

Sexton, T.R., Silkman, R.H., \& Logan, A.J. (1986). Data envelopment analysis: Critique and extensions. In H. Silkman, (Ed.), Measuring efficiency: An assessment of data envelopment analysis. San Francisco: Jossey-Bass.

Shelton, R.D., \& Leydesdorff, L. (2012). Publish or patent: Bibliometric evidence for empirical trade-offs in national funding strategies. Journal of the American Society for Information Science \& Technology, 63(3), 498-511.

Sicsu, J., \& Oliveira, S.C. (2003). Taxa de juros e controle da inflação no Brasil. In J. Sicsu, J.L. Oreiro, L.F. Paula (Eds.), Agenda Brasil: políticas econômicas para o crescimento com estabilidade de preços. São Paulo, Brazil: Monole.

Soares de Mello, J.C.C.B., Meza, L.A., \& da Silva, B.B. (2008). Some rankings for the Athens Olympic Games using DEA model with a constant input. Investigação Operacional, 28, 77-89.

Storey, D.J., \& Tether, B. (1998). New Technology-based firms in the European Union: An introduction. Research Policy, 26, 933946.

UNESCO. (2010). UNESCO science report 2010. Paris: UNESCO Publishing.

Wonglimpiyarat, J. (2010). Commercialization strategies of technology: Lessons from Silicon Valley. Journal of Technology Transfer, 35(2), 225-236.

Zhu, J. (2009). Quantitative models for performance evaluation and benchmarking: Data envelopment analtsis with spreadsheets. New York: Springer. 